\title{
DI BALIK PREVALENSI PERKAWINAN USIA ANAK YANG MENGGELISAHKAN: HUKUM NEGARA VERSUS HUKUM ADAT
}

\author{
BEHIND CONCERNING PREVALENCE OF CHILDREN AGE \\ MARRIAGE: STATE LAW VERSUS ADAT LAW
}

\author{
I Ketut Sudantra \\ Dosen Fakultas Hukum Universitas Udayana, Denpasar \\ E-mail: sudantra01@yahoo.co.id \\ I Gusti Ngurah Dharma Laksana \\ 1Dosen Fakultas Hukum Universitas Udayana, Denpasar \\ E-mail: ngurahdharmalaksana@yahoo.com
}

\begin{abstract}
Marriage is a form of legal event, so that it believed there is legal aspect that influences the high prevalence of children age marriage in Indonesia, including Bali. Marriage law that applies to adat society in Bali has pluralistic nature, because there are more than one legal system that apply on the same social field, which are state law system (national marriage law) and adat legal system (Balinese adat law). This study aim to review regulation of children age marriage on both system, are they synchronize or not? Method used is normative legal research method with statute approach and conceptual approach. This research rely on secondary data, both in form of legal source (primary and secondary) and non-legal source, that were gathered through literature search. Analysis was done with legal argumentation and reasoning techniques, like legal construction and interpretation. Result shown that there is no conformity in regulation of children age marriage in Indonesian legal system, neither on internal environment of national law, nor on dichotomy of state law and (Balinese) adat law. That's why legal synchronization is needed to end or at least decrease the practice of children age marriage in Indonesia.
\end{abstract}

Keywords: daha teruna, Balinese adat law, national marriage law, children age marriage, legal pluralism

\begin{abstract}
Abstrak
Perkawinan adalah suatu peristiwa hukum sehingga diyakini ada aspek hukum yang berpengaruh terhadap masih tingginya prevalensi perkawinan usia anak di Indonesia, termasuk Bali. Hukum perkawinan yang berlaku bagi masyarakat adat di Bali bersifat pluralistik sebab berlaku lebih dari satu sistem hukum dalam lapangan sosial yang sama, yaitu sistem hukum negara (hukum perkawinan nasional) dan sistem hukum adat (hukum adat Bali). Penelitian ini bertujuan untuk mengkaji pengaturan perkawinan usia anak dalam dua sistem hukum tersebut, apakah sinkron atau tidak. Metode yang digunakan adalah metode penelitian hukum normatif dengan pendekatan perundang-undangan (statute approach) dan pendekatan konseptual (conceptual approach). Penelitian ini mengandalkan data sekunder, baik yang berupa bahan hukum (primer dan sekunder) maupun bahan non-hukum, yang dikumpulkan melalui penelusuran literatur. Analisis dilakukan dengan teknik-teknik penalaran dan argumentasi hukum, seperti penafsiran dan konstruksi hukum. Hasil penelitian menunjukkan bahwa tidak ada kesesuaian
\end{abstract}


pengaturan perkawinan usia anak dalam sistem hukum di Indonesia, baik dalam lingkup internal hukum negara maupun dalam dikotomi hukum negara dan hukum adat (Bali). Itu sebabnya ada kebutuhan perlunya sinkronisasi hukum untuk dapat mengakhiri atau setidaknya mengurangi praktik-praktik perkawinan usia anak di Indonesia.

\section{Kata kunci: Daha Teruna, Hukum Adat Bali, Hukum Perkawinan Nasional, Per- kawinan Usia Anak, Pluralisme Hukum.}

\section{PENDAHULUAN}

Kasus perkawinan usia anak yang sempat menyita perhatian publik terjadi tahun 2008 ketika di Semarang seorang laki-laki yang sudah menikah tiga kali menikahi secara siri seorang anak perempuan berumur 12 tahun. Perkawinan itu menjadi polemik dalam masyarakat, di samping karena perilaku perkawinan poligami itu sendiri, juga karena terjadi perbedaan persepsi mengenai boleh atau tidaknya perkawinan dilakukan dengan perempuan yang masih berada pada usia anak. Pihak yang kontra terhadap perkawinan usia anak berpandangan bahwa secara hukum perkawinan usia anak tidak diperbolehkan oleh peraturan perundang-undangan, baik oleh Undang-undang Perkawinan maupun Undang-undang Perlindungan Anak; sedangkan pihak yang pro berpendapat bahwa perkawinan usia anak boleh saja dilakukan karena tidak bertentangan dengan ajaran agama ${ }^{1}$.

April 2018, terjadi lagi kehebohan ketika dua pelajar Sekolah Menengah Pertama di Sulawesi Selatan mendaftarkan diri untuk melakukan perkawinan di Kantor Urusan Agama (KUA) Kecamatan Bantaeng, Sulawesi Selatan. Calon mempelai pria masih berusia 15 tahun 10 bulan, sedangkan calon mempelai perempuan masih berusia 14 tahn 9 bulan. Permohonan ini sempat ditolak oleh KUA, tetapi karena Pengadilan Agama Bantaeng memberikan dispensasi, akhirnya KUA Bantaeng memproses perkawinan usia anak tersebut. Dispensasi Pengadilan Agama dikeluarkan berdasarkan permohonan pihak keluarga dari calon mempelai².

Di Bali, kehebohan perkawinan usia anak juga pernah terjadi, Januari 2013, ketika seorang siswi kelas enam Sekolah Dasar yang telah mengandung tujuh bulan dikawinkan secara adat dengan laki-laki 40 tahun yang sudah beristri. Upacara pengesahan perkawinan dilakukan menurut agama Hindu dan adat Bali yang disebut beakawon. Berdasarkan Undang-undang Nomor 1 Tahun 1974 tentang Perkawinan, perkawinan adalah sah apabila sudah dilakukan menurut agama dan kepercayaannya masing-masing. Kejadian yang terjadi di Desa Jehem, Kecamatan Tembuku, Kabupaten Bangli, itu menimbulkan polemik dalam masyarakat Bali. Bendesa Adat Jehem selaku kepala adat setempat menyatakan perkawinan usia anak itu disahkan karena dua alasan. Alasan pertama, perkawinan itu dilandasi oleh perasaan cinta sama cinta kedua mempelai. Alasan kedua, pengesahan perkawinan dilakukan untuk mencegah terjadinya keletehan (kekotoran gaib) pada wilayah desa setempat sebagai akibat adanya kehamilan di luar perkawinan yang $\mathrm{sah}^{3}$

\footnotetext{
${ }^{1}$ Hamzah. "Pernikahan Di Bawah Umur (Analisis tentang Konsekuensi Pemidanaan)." Al Daulah: Jurnal Hukum Pidana dan Ketatanegaraan . 6.1 (2017): 86-120. http://journal.uin-alauddin.ac.id/index.php/al daulah/articlel view/4869/4357, diakses tanggal 18 Agustus 2018

${ }^{2}$ Kristian Erdianto, "Presiden Jokowi Harus Melihat, Perkawinan Anak Sudah Darurat", https://nasional.kompas.com/read/2018/04/18/06430291/presiden-jokowi-harus-melihat-perkawinan-anak-sudah-darurat, diakses tanggal 18 Agustus 2018.

3 Rohmat, LPA Bali Telusuri Kasus Pernikahan Bocah SD dan Pria 40 Tahun, https://news.okezone.com/ read/2013/01/30/340/753711/lpa-bali-telusuri-kasus-pernikahan-bocah-sd-dan-pria-40-tahun, diakses tanggal 18 Agustus 2018.
} 
Kasus-kasus di atas yang terungkap di media tampaknya hanya merupakan puncak fenomena gunung es, sebab ternyata perkawinan usia anak masih banyak terjadi di Indonesia. Temuan penelitian yang dilakukan Plan Indonesia selama Januari-April 2011 di delapan kabupaten di seluruh Indonesia (Kabupaten Indramayu, Jawa Barat; Grobogan, Rembang, Jawa Tengah; Tabanan, Bali; Dompu, Nusa Tenggara Barat; Timor Tengah Selatan, Sikka, dan Lembata, Nusa Tenggara Timur) sungguh menggelisahkan. Dari penelitian itu diketahui bahwa 33,5 \% anak usia 13-18 tahun pernah menikah. Walaupun penelitian tersebut tidak mewakili seluruh populasi di Indonesia, temuan ini bisa menjadi gambaran umum kasus-kasus perkawinan di bawah umur secara umum di Indonesia. Data ini tak jauh berbeda dengan temuan Badan Perencanaan Pembangunan Nasional Republik Indonesia sebelumnya (2008), bahwa 34,5 \% dari 2.049 .000 perkawinan tahun 2008 adalah perkawinan usia anak ${ }^{4}$

Dewasa ini, prevalensi perkawinan usia anak di Indonesia masih menggelisahkan sebab masih menunjukkan angka yang cukup tinggi. Menurut laporan Badan Pusat Statistik - UNICEF (2016), memang terjadi penurunan yang cukup signifikan pada angka perkawinan usia anak di Indonesia dalam tiga dekade terakhir, tetapi angka perkawinan usia anak di Indonesia masih termasuk salah satu yang tertinggi di kawasan Asia Timur dan Pasifik ${ }^{5}$. Laporan terbaru (2017) menunjukkan prevalensi perkawinan usia anak tahun 2013 berada pada angka 24\% sedangkan tahun 2015 masih berada pada angka $23 \%$. Itu menunjukan penurunan yang sangat lambat. Di Bali, walaupun prevalensinya lebih rendah dari rata-rata nasional, kondisi serupa juga terjadi, bahkan cendrung stagnan $(2013: 16,73 \% ; 2015: 16,37 \%)^{6}$

Perkawinan usia anak menimbulkan dampak buruk bagi anak: merenggut masa remaja anak yang seharusnya menjadi masa perkembangan fisik, emosi dan sosial anak; menimbulkan dampak buruk terhadap status kesehatan, pendidikan dan keamanan anak. Dari perspektif hukum, perkawinan usia anak melanggar hak-hak anak yang ditentukan dalam berbagai instrumen hukum perlindungan anak, meliputi hak atas pendidikan, hak atas kesehatan, hak untuk hidup bebas dari kekerasan (termasuk seksual), hak untuk dilindungi dari eksploatasi, hak untuk tidak dipisahkan dari orang tua mereka. Oleh karena itu, dalam rangka mewujudkan perlindungan terhadap hak anak, perlu dicarikan solusi terhadap problem masih tinggi dan lambatnya penurunan angka perkawinan usia anak di Indonesia pada umumnya dan Bali pada khususnya.

Untuk dapat merumuskan solusi yang tepat, penting diidentifikasi problem-problem yang menyebabkan masih tinggi dan stagnannya angka perkawinan usia anak. Tentu banyak aspek yang berpengaruh terhadap masih tinggi dan stagnannya angka perkawinan usia anak. Salah satu aspek yang penting dikaji adalah aspek hukum, sebab perkawinan bukanlah peristiwa biasa yang hanya menjadi urusan antara dua orang yang kawin saja, melainkan merupakan suatu peristiwa hukum. Sebagai suatu peristiwa hukum, perkawinan diatur oleh hukum dan menimbulkan akibat-akibat hukum tertentu, baik akibat terhadap kedudukan orang-orang yang melakukan perkawinan (suami-istri); akibat terhadap kedudukan anak yang lahir dari perkawinan tersebut; dan akibat terhadap harta yang dibawa oleh masing-masing pihak ke dalam perkawinan atau pun harta yang diperoleh setelah berlangsungnya perkawinan.

\footnotetext{
${ }^{4}$ Liputan6, "Pernikahan Dini, Fenomena Gunung Es", https:/www.liputan6.com/news/read/354833/pernikahan-dini-fenomena-gunung-es, diakses tanggal 18 Agustus 2018.

${ }^{5}$ Subdirektorat Statistik Rumah Tangga, 2016, Kemajuan Yang Tertunda: Analisis Data Perkawinan Usia Anak di Indonesia, Badan Pusat Statistik - UNICEF, Jakarta, hlm.1

${ }^{6}$ Direktorat Statistik Kesejahteraan Rakyat, 2017, Perkawinan Usia Anak di Indonesia (2013 dan 2015), Edisi Revisi, Badan Pusat Statistik-UNICEF Indonesia, Jakarta, hlm. 7 \& 55,
} 
Berkaitan dengan aspek hukum perkawinan, penelitian yang telah dilakukan oleh Sudantra \& Laksana ${ }^{7}$ menunjukkan bahwa hukum perkawinan yang berlaku bagi umat Hindu di Bali bersifat pluralistik (pluralisme hukum), yaitu berlaku lebih dari satu sistem hukum perkawinan, dalam hal ini hukum perkawinan nasional dan hukum adat Bali. Hukum perkawinan nasional yang dimaksudkan di sini adalah sistem hukum negara yang mengatur masalah perkawinan di bawah payung Undang-undang Nomor 1 tahun 1974 tentang Perkawinan. Undang-undang ini berlaku bagi seluruh warga negara Indonesia dan pelaksanaannya mulai berlaku efektif sejak Oktober 1975. Hukum adat Bali yang dimaksudkan di sini adalah hukum adat yang berlaku di kalangan masyarakat etnis Bali beragama Hindu yang dikenal sebagai masyarakat adat Bali. Hukum adat Bali ini sebagian dapat diidentifikasi dari awig-awig desa pakraman dan sebagian lainnya dapat dikenali dari dresta yaitu kebiasaan-kebiasaan yang tumbuh dan dipraktikkan dalam kehidupan masyarakat. Awig-awig desa pakraman adalah peraturan-peraturan adat yang dibuat secara musyawarah mufakat oleh masyarakat dari kesatuan-kesatuan masyarakat hukum adat teritorial yang ada di Bali. Kesatuan-kesatuan masyarakat hukum adat ini disebut desa pakraman ${ }^{8}$.

Problem yang umum terjadi dalam suasana berlakunya pluralisme hukum adalah problem sinkronisiasi hukum. I Nyoman Nurjaya menjelaskan bahwa konsep pluralisme hukum secara umum digunakan untuk menjelaskan suatu situasi di mana dua atau lebih sistem hukum berlaku secara berdampingan dalam satu bidang kehidupan sosial (social field); atau untuk menjelaskan keberadaan dua atau lebih sistem pengendalian sosial yang berlaku dalam masyarakat; atau menerangkan suatu situasi di mana dua atau lebih sistem hukum berinteraksi dalam satu kehidupan sosial; atau suatu kondisi di mana dua atau lebih sistem hukum bekerja secara berdampingan dalam aktivitas dan hubungan dalam masyarakat ${ }^{9}$.. Dengan berlakunya lebih dari satu sistem hukum dalam bidang kehidupan yang sama, adakalanya sistem-sistem hukum tersebut berlaku secara berdampingan, saling melengkapi, berkontestasi, bahkan berkonflik. Bentuk relasi sistem-sistem hukum tersebut akan sangat mempengaruhi efektivitas sistem hukum tersebut dalam mewujudkan tujuannya. Apabila sistem hukum tersebut dapat saling melengkapi, tentu hal itu tidak menjadi masalah. Tetapi ketika sistem-sistem hukum tersebut saling berkontestasi apalagi berkonflik, itu akan menyebabkan kurang atau tidak efektifnya sistem hukum tersebut dalam mewujudkan tujuannya. Oleh karena itu, penting diketahui, apakah terdapat sinkronisasi antara sistem hukum negara dan hukum adat Bali dalam pengaturan perkawinan usia anak. Untuk dapat mengetahui hal tersebut, pertama-tama harus diketahui bagaimana masing-masing sistem hukum tersebut mengatur perkawinan usia anak. Tulisan ini akan berusaha menjawab pertanyaan tersebut.

Artikel ini ditulis berdasarkan hasil penelitian yang menggunakan metode penelitian kepustakaan (library research) yang dalam studi hukum disebut penelitian hukum

${ }^{7}$ I Ketut Sudantra dan I Gusti Ngurah Dharma Laksana, 2017, "Pluralisme Hukum Yang Berlaku dalam Perkawinan Umat Hindu di Bali", Prosiding Seminar Sains \& Teknologi IV 2017, Lembaga Penelitian dan Pengabdian Kepada Masyarakat Universitas Udayana -Udayana University Press, hlm. 159.

${ }^{8}$ I Ketut Sudantra,.Ni Nyoman Sukerti, A.A. Istri Ari Atu Dewi, "Identifikasi Lingkup Isi dan Batas-batas Otonomi Desa Pakraman dalam Hubungannya dengan Kekuasaan Negara." Jurnal Magister Hukum Udayana (Udayana Master Law Journal) 4.1 (2015), hlm. 18, https://ojs.unud.ac.id/index.php/jmhu/article/view/13052/10829, diakses tanggal 2 September 2018.

${ }^{9}$ I Nyoman Nurjaya, "Constitutional And Legal Recognition Over Traditional Adat Community Within The Multicultural Country of Indonesia : Is It A Genuine Or Pseudo Recognition?", Jurnal IUS Kajian Hukum dan Keadilan 2.3 (2014), hlm. 421, file:///E:/A.\% 20JURNAL/MAKALAH \% 20ASING/PLURALISME \% 20HUKUM \% 20-\% 20 NURJAYA \% 20JURNAL\% 20IUS.pdf, diakses tanggal 12 Maret 2919, 
normatif atau penelitian hukum doktrinal ${ }^{10}$. Data yang digunakan dalam penelitian ini adalah data sekunder, yang meliputi bahan-bahan hukum (primer dan sekunder) dan bahan non-hukum. Bahan hukum primer yang digunakan untuk meneliti hukum negara adalah Undang-undang Nomor 1 Tahun 1974 tentang Perkawinan serta undangundang lain yang mengatur masalah anak, seperti Undang-undang Undang-undang Perlindungan Anak (Undang-undang Nomor 23 Tahun 2002 yang telah diubah dengan Undang-undang Nomor 35 Tahun 2014). Bahan hukum primer untuk meneliti hukum adat Bali digunakan awig-awig desa pakraman yang mewakili masing-masing kabupaten/ kota yang ada di Bali. Untuk kepentingan analisis hukum, digunakan bahan hukum sekunder berupa literatur hukum yang relevan. Di samping itu, sebagai penunjang digunakan juga bahan-bahan non-hukum berupa statistik untuk mengetahui kondisi perkawinan usia anak dan kamus bahasa Bali untuk menterjemahkan materi awig-awig desa pakraman dan menafsirkan konsep-konsep hukum adat Bali.

Pengumpulan bahan hukum sebagian dilakukan dengan teknik penelusuran literatur diperpustakaan dan internet. Khusus untuk pengumpulan awig-awig desa pakraman dilakukan langsung dari desa pakraman yang dijadikan sampel penelitian. Bahan-bahan penelitian yang telah terkumpul selanjutnya diolah dan dianalisis secara kualitatif dengan teknik-teknik penalaran dan argumentasi hukum, seperti konstruksi hukum dan penafsiran hukum. Penyajian dilakukan secara deskreftif dalam bentuk uraian naratif

\section{PEMBAHASAN}

\section{Konsep Perkawinan Usia Anak}

Sampai hari ini belum ditemukan difinisi yuridis tentang perkawinan usia anak. Bahkan, peristilahan yang digunakan oleh berbagai pihak juga beragam.. Dalam berbagai tulisan, perkawinan usia anak kadang-kadang di disebut dengan istilah "perkawinan anak"11, "perkawinan dibawah umur"12, atau "pernikahan dini"13. Istilah "perkawinan usia anak" yang digunakan dalam tulisan ini mengikuti istilah yang secara konsistem digunakan oleh Badan Pusat Statistik (BPS) ${ }^{14}$ dalam laporan-laporannya.

Kesulitan mendifinisikan perkawinan usia anak antara lain disebabkan karena peraturan perundang-undangan yang berlaku di Indonesia menggunakan batasan umur yang berbeda untuk difinisi anak. Pada umumnya undang-undang yang berlaku sekarang menggunakan batasan umur 18 tahun untuk anak, tetapi masih ada undangundang lain yang menggunakan kriteria berbeda. Undang-undang Ketenagakerjaan pernah menggunakan usia di bawah 15 (lima belas) tahun untuk mendifinisikan anak (Undang-undang Nomor 25 Tahun 1997). Undang-undang Nomor 4 Tahun 1979 tentang Kesejahteraan Anak menidifinisikan anak sebagai seseorang yang belum berusia 21 tahun. Apabila difinisi anak dalam undang-undang ini yang digunakan, maka perkawinan seseorang yang berusia antara 19 - 20 tahun masih tergolong sebagai perkawinan usia anak. Di lain pihak, Undang-undang tentang Perlindungan Anak, yaitu

\footnotetext{
${ }^{10}$ Jonaedi Efendi \& Johnny Ibrahim, 2018, Metode Penelitian Hukum Normatif dan Empiris, cetakan kedua, Prenadamedia Group, Indonesia, hlm. 124.

${ }^{11}$ Djamilah \& Reni Kartikawati, "Dampak Perkawinan Anak", Jurnal Studi Pemuda 3.1 (2014), hlm. 1. https:// jurnal.ugm.ac.id/jurnalpemuda/article/view/32033/19357, diakses tanggal 12 Maret 2019.

${ }^{12}$ Hamzah, op.cit., hlm. 1.

${ }^{13}$ Dwi Rifiani, "Pernikahan Dini dalam Perspektif Hukum Islam”, Journal De Jure 3.1., hlm. 1 http://ejournal. uin-malang.ac.id/index.php/syariah/article/view/2144, diakses tanggal 12 Maret 2019.

${ }^{14}$ Direktorat Statistik Kesejahteraan Rakyat, op.cit., hlm. 1; Subdirektorat Statistik Rumah Tangga, op.cit., hlm. 1
} 
Undang-undang Nomor 23 Tahun 2002 (sebagaimana diubah dengan Undang-undang Nomor 35 Tahun 2014) mendifinisikan anak dalam Pasal 1 dengan menyatakan: "Anak adalah seseorang yang belum berumur 18 (delapan belas) tahun, termasuk anak yang masih dalam kandungan". Undang-undang Nomor 44 Tahun 2008 tentang Pornografi dengan tegas menentukan difinisi anak adalah orang yang belum berumur 18 (delapan belas) tahun. Demikian juga Undang-undang Ketenagakerjaan yang kini berlaku, yaitu Undang-undang Nomor 13 Tahun 2003 sudah menggunakan batasan belum berusia 18 tahun sebagai kriteria anak (Pasal 1 angka 26). Sejumlah undang-undang lain juga menggunakan kriteria belum berumur 18 (delapan belas) tahun untuk mendifinisikan anak, seperti dapat ditemukan dalam Undang-undang Nomor 39 Tahun 1999 tentang Hak Asasi Manusia (Pasal 1 angka 5); Undang-undang Nomor 11 Tahun 2012 tentang Sistem Peradilan Pidana Anak (Pasal 1 angka 2 dan angka 3); dan Undang-undang Nomor 30 Tahun 2004 sebagaimana diubah dengan Undang-undang Nomor 2 Tahun 2014 yang mengatur jabatan notaris.

Kreteria "belum berumur 18 tahun" sebagai kreteria untuk mendifinisikan anak tampaknya menyesuaikan dengan difinisi anak yang dianut oleh hukum internasional seperti yang ditentukan dalam Konvensi Hak-hak Anak (Convention On The Rights of The Child). Pasal 1 Konvensi Hak Anak menentukan bahwa: "Yang dimaksud anak dalam Konvensi ini adalah setiap orang yang berusia di bawah 18 tahun, kecuali berdasarkan undang-undang yang berlaku bagi anak ditentukan bahwa usia dewasa dicapai lebih awal". Konvensi ini disetujui oleh Majelis Umum Perserikatan Bangsa-Bangsa (PBB), 20 November 1989 melalui Resolusi 44/25 dan mulai berlaku pada 2 September 1990. Indonesia meratifikasi konvensi ini tangal 25 Agustus 1990 melalui Keputusan Presiden No. 36/1990 dan dinyatakan mulai berlaku di Indonesia sejak 5 Oktober $1990^{15}$. Sejak itu, kecendrungan pengaturan mengenai kriteria anak mengacu kepada Konvensi Hakhak Anak.

Dengan mengikuti kecendrungan peraturan perundang-undangan dalam mendifinisikan anak, dalam penelitian ini dapat dirumuskan konsep perkawinan usia anak sebagai perkawinan yang dilakukan oleh seseorang yang belum berusia 18 (delapan belas) tahun. Difinisi ini sesuai pula dengan difinisi yang digunakan oleh BPS dalam mengukur tingkat perkawinan usia anak di Indonesia. Dalam laporan Subdirektorat Statistik Rumah Tangga BPS-UNICEF, perkawinan usia anak didifinisikan sebagai "perkawinan yang dilakukan melalui hukum perdata, agama atau adat, dengan atau tanpa pencatatan atau persetujuan resmi dimana salah satu atau kedua pasangan adalah anak-anak di bawah usia 18 tahun"16

\section{Perkawinan Usia Anak dalam Perspektif Hukum Perkawinan Nasional}

Dalam Undang-undang Perkawinan, terdapat beberapa ketentuan yang mengatur masalah umur seseorang yang aka melangsungkan perkawinan. Pertama, Pasal 6 yang menentukan sebagai berikut:

(1)Perkawinan harus didasarkan atas persetujuan kedua calon mempelai.

(2)Untuk melangsungkan perkawinan seorang yang belum mencapai umur 21 (dua puluh satu) tahun harus mendapat izin kedua orang tua;

(3)Dalam hal salah seorang dari kedua orang tua telah meninggal dunia atau dalam keadaan tidak mampu menyatakan kehendaknya maka izin dimaksud ayat (2) pasal

\footnotetext{
${ }^{15}$ Zendy Wulan Ayu Widhi Prameswari, "Ratifikasi Konvensi tentang Hak-hak Anak dalam Sistem Perundang-undangan di Indonesia", Yuridika, Vol. 32 No. 1 Januari 2017, hal.169, https://e-journal.unair.ac.id/YDK/article/view/4842/pdf, diakses tanggal 23 Agustus 2018

${ }^{16}$ Subdirektorat Statistik Rumah Tangga, op.cit., hlm. 6 .
} 
ini cukup diperoleh dari orang tua yang masih hidup atau dari orang tua yang mampu menyatakan kehendaknya.

(4)Dalam hal kedua orang tua sudah meninggal dunia atau dalam keadaan tidak mampu untuk menyatakan kehendaknya maka izin diperoleh dari wali, orang yang memelihara atau keluarga yang mempunyai hubungan darah dalam garis keturunan lurus ke atas selama mereka masih hidup dan dalam keadaan dapat menyatakan kehendaknya.

(5)Dalam hal ada perbedaan pendapat antara orang-orang yang disebut dalam ayat (2), (3), dan (4) pasal ini, atau salah seorang atau lebih di antara mereka tidak menyatakan pendapatnya, maka Pengadilan dalam daerah hukum tempat tinggal orang yang akan melangsungkan perkawinan atas permintaan orang tersebut dapat memberikan izin setelah lebih dulu mendengar orang-orang tersebut dalam ayat (2), (3) dan (4) pasal ini.

(6)Ketentuan tersebut ayat (1) sampai dengan ayat (5) pasal ini berlaku sepanjang hukum masing-masing agamanya dan kepercayaannya itu dari yang bersangkutan tidak menentukan lain.

Ketentuan ini secara acontrario dapat ditafsirkan bahwa seseorang yang belum mencapai umur 21 tahun tidak diijinkan melakukan perkawinan, kecuali ada izin dari orang tua. Dalam hal orang tua telah meninggal dunia atau berada dalam keadaan tidak mampu menyatakan kehendaknya izin diberikan oleh wali.

Ketentuan ini menunjukkan bahwa seseorang yang belum genap berusia 21 tahun berada dalam keadaan hukum belum dewasa (minderjarig). Secara yuridis, orang yang belum dewasa tidak cakap melakukan perbuatan hukum termasuk dalam melakukan perkawinan. Perkawinan adalah suatu perbuatan hukum karena perbuatan tersebut menimbulkan akibat-akibat hukum tertentu, baik terhadap kedudukan suami dan istri maupun kedudukan anak-anak yang lahir dari perkawinan tersebut. Perkawinan juga merupakan suatu perjanjian (perikatan). Itu tegas dinyatakan dalam Pasal 1 Undangundang Perkawinan yang menyatakan bahwa "Perkawinan ialah ikatan lahir batin antara seorang pria dengan seorang wanita sebagai suami istri dengan tujuan untuk membentuk keluarga (rumah tangga) yang bahagia dan kekal berdasarkan Ketuhanan Yang Maha Esa". Dalam hukum perjanjian terdapat dua syarat subyektif yang harus dipenuhi oleh para pihak yang mengadakan perjanjian. Pertama, perjanjian harus didasari oleh persetujuan kedua belah pihak. Syarat subyektif kedua, para pihak yang melakukan perjanjian harus dalam keadaan cakap bertindak. Apabila syarat subyektif tersebut tidak dipenuhi maka suatu perjanjian dapat dibatalkan melalui putusan Pengadilan ${ }^{17}$. Dikaitkan dengan perkawinan, Pasal 6 ayat 1 dan ayat 2 adalah syarat subyektif yang harus dipenuhi oleh para pihak yang akan melangsungkan perkawinan, sehingga seseorang yang belum berusia 21 tahun tidak boleh melakukan perkawinan, kecuali atas ijin orang tua.

Berkaitan dengan ijin orang tua kepada anaknya untuk melangsungkan perkawinan ini, orang tua tidak dapat bertindak sembarangan memberikan ijin tanpa memperhatikan umur anaknya. Undang-undang Perkawinan memberikan batasan yang tegas, melalui Pasal 7. Selengkapnya ketentuan Pasal 7 Undang-undang Perkawinan menentukan sebagai berikut:

(1)Perkawinan hanya diizinkanjika pihak pria sudah mencapai umur 19 (sembilan belas) tahun dan pihak wanita sudah mencapai umur 16 (enam belas) tahun.

${ }^{17}$ R. M. Panggabean,. "Keabsahan Perjanjian dengan Klausul Baku." Jurnal Hukum Ius Quia Iustum 17.4 (2010), hlm. 669. http://journal.uii.ac.id/IUSTUM/article/view/3935/3514, diakses tanggal 22 Agustus 2018. 
(2)Dalam hal penyimpangan terhadap ayat (1) pasal ini dapat meminta dispensasi kepada Pengadilan atau pejabat lain yang ditunjuk oleh kedua orang tua pihak pria maupun pihak wanita.

Dengan demikian, orang tua baru dapat mengijinkan anaknya untuk melangsungkan perkawinan jika anaknya sudah memenuhi batas umur yang ditentukan oleh Pasal 7 , yaitu 19 (sembilan belas) tahun untuk pria atau 16 (enam belas) tahun untuk wanita.

Beberapa kalangan berpandangan bahwa batas usia perkawinan yang ditentukan oleh Undang-undang Perkawinan bersifat diskriminatif dan tidak adil bagi perempuan. Di samping memberikan patokan umur yang berbeda antara laki-laki dan perempuan, juga memberi patokan umur terlalu muda bagi seseorang, terutama perempuan, untuk melakukan perkawinan. Oleh karena itu, tahun 2014 dua yayasan, yaitu Yayasan Kesehatan Perempuan (Perkara No 30/PUU-XII/2014) dan Yayasan Pemantauan Hak Anak (Perkara No 74/PUU-XII/2014.) melakukan uji materi ketentuan Pasal 7 ayat (1) Undang-undang Perkawinan di Mahkamah Konstitusi. Alasan-alasan pemohon melakukan uji materi dapat diidentifikasi, antara lain: (1) norma yang terkandung dalam Pasal 7 ayat (1) sepanjang frasa "16 (enam belas) tahun" bertentangan dengan sejumlah pasal dalam UUD 1945; (2) perkawinan usia anak menimbulkan dampak adanya kemahilan dalam usia dini yang dapat menimbulkan risiko bagi ibu dan anak, seperti: potensi kesulitan dan kerentanan saat hamil dan melahirkan anak secara prematur, melahirkan anak kurang gizi, dan lain-lain; (3) perkawinan usia anak menghalangi kesempatan mereka untuk mengembangkan potensinya untuk menjadi orang dewasa yang mandiri, berpengetahuan dan berdayaguna; (4) anak perempuan yang sudah kawin saat masih anak-anak mudah terekspos terhadap berbagai bentuk penindasan dan kekerasan dalam perkawinan; (5) batas usia perkawinan anak perempuan dalam Undang-undang Perkawinan tidak sesuai dengan peraturan perundang-undangan yang berlaku, terutama dalam rangka melindungihak-hak anak, khususnya anak perempuan. ${ }^{18}$. Dalam sebagian petitum pemohon, pemohon meminta kepada Mahkamah Konstitusi agar: (1) menyatakan bahwa materi muatan Pasal 7 ayat (1) Undang-undang Perkawinan sepanjang mengenai frasa "16 (enam belas) tahun" harus dimaknai secara inkonstitusional bersyarat (conditionally unconstitutional) sehingga bertentangan dengan Undang-undang Dasar 1945 sepanjang tidak dimaknai "18 (delapan) belas tahun"; (2) menyatakan bahwa materi muatan Pasal 7 ayat (1) Undang-undang Perkawinan sepanjang mengenai frasa "16 (enam belas) tahun" harus dimaknai secara inkonstitusional bersyarat (conditionally unconstitutional) sehingga tidak mempunyai kekuatan hukum mengikat sepanjang tidak dimaknai "18 (delapan belas) tahun; (3) mengubah materi muatan Pasal 7 ayat (1) Undang-undang Perkawinan menjadi "Perkawinan hanya diizinkan jika pihak pria sudah mencapai umur 19 (sembilan belas) tahun dan pihak wanita sudah mencapai unur 18 (delapan belas) tahun"19. Tetapi Mahkamah Konstitusi RI, melalui Putusan Nomor 30-74/PUUXII/2014, menolak mengabulkan permohonan untuk menaikkan batas usia perkawinan seorang wanita dari 16 (enam belas) tahun menjadi 18 (delapan belas) tahun dengan alasan bahwa pokok permohonan Pemohon tidak beralasan menurut hukum.

${ }^{18}$ Hasanain Haikal dan Abdul Hadi, "Analisis Yuridis Normatif Dan Hukum Islam Terhadap Putusan Mahkamah Konstitusi Nomor 30- 74/PUU-XII/2014 Tentang Batas Usia Perkawinan Anak (Perempuan)" , Yudisia Jurnal Pemikiran Hukum dan Hukum Islam 7.1 Juni 2016, hlm. 244, http://journal.stainkudus.ac.id/index.php/Yudisia/ article/view/2138/1770. diakses tanggal 3 September 2018.

${ }^{19}$ Ahmad Masfuful Fuad, "Menelaah Kembali Ketentuan Usia Minimal Kawin di Indonesia Melalui Perspektif Hermeneutika." Al-Maslahah 11.2 (2015)., hlm. 2, https://jurnaliainpontianak.or.id/index.php/Almaslahah/article/ view/145/254, diakses tanggal 23 Agustus 2018. 
April 2017, ketentuan Pasal 7 ayat (1) Undang-undang Perkawinan kembali digugat di Mahkmah Konstitusi RI oleh tiga perempuan korban perkawinan anak, yaitu Endang Wasrinah, Maryanti dan Rasminah. Dalam pernyataan Tim Kuasa Hukum Koalisi $18+$ yang mewakili mereka dinyatakan bahwa Putusan Mahkamah Konstitusi Nomor 30-74/ PUU-XII/2014 yang menyatakan bahwa Pasal 7 ayat (1) dan ayat (2) UU Perkawinan tidak bertentangan dengan UUD 1945 telah menguatkan praktek perkawinan usia anak serta menimbulkan diskriminasi dan melanggengkan ketidaksetaraan kedudukan hukum bagi anak perempuan. Tiga perempuan korban perkawinan anak menganggap negara masih lalai memberikan perlindungan pada perempuan dari praktek perkawinan anak sehingga mereka mengajukan judicial riview atas ketentuan pasal 7 ayat (1) Undangundang Perkawinan di Mahkamah Konstitusi. Adapun alasan-alasan permohonan adalah ketentuan Pasal 7 ayat (1) Undang-undang Perkawinan sepanjang frasa "16 (enam belas) tahun" melanggar prinsip segala warga negara bersamaan kedudukannya di dalam hukum, sehingga bertentangan dengan Pasal 27 ayat (1) Undang-undang dasar Negara Republik Indonesia Tahun 1945; menimbulkan pembedaan kedudukan hukum dan diskriminasi terhadap anak perempuan dalam hak kesehatan dan hak pendidikan; dan menimbulkan risiko eksploatasi anak perempuan ${ }^{20}$. Akhirnya Mahkamah Konstitusi dalam putusan yang dibacakan pada tanggal 13 Desember 2018 menyetujui alasan para pemohon dan menyatakan bahwa ketentuan Pasal 7 ayat (1) Undang-undang Perkawinan bersifat diskriminatif. Kendati menolak menentukan batas usia minimal usia perkawinan karena itu adalah wewenang Dewan Perwakilan Rakyat, Mahkamah Konstitusi meminta pembuat undang-undang agar paling lambat dalam 3 tahun melakukan perubahan terhadap Undang-undang Perkawinan, khususnya menyangkut batas usia minimal perempuan dalam perkawinan ${ }^{21}$. Putusan Mahkamah Konstitusi terbaru ini tidak serta merta mengakibatkan ketentuan Pasal 7 ayat (1) Undang-undang Perkawinan menjadi tidak berlaku. Sebelum direvisi, ketentuan tersebut masih tetap berlaku.

Dari uraian di atas di atas dapat dipahami bahwa berdasarkan hukum perkawinan nasional seseorang yang belum berusia 21 tahun berada dalam keadaan hukum belum dewasa sehingga tidak boleh melakukan perkawinan, kecuali mendapat izin dari orang tua/wali atau dispensasi dari Pengadilan. Izin orang tua dapat diberikan apabila orang yang akan melangsungkan perkawinan tersebut sudah mencapai batas usia tertentu, yaitu pria sudah mencapai umur 19 tahun dan wanita sudah berumur 16 tahun. Khusus mengenai ketentuan bahwa wanita dizinkan melakukan perkawinan pada usia 16 (enam belas) tahun tidak sinkron dengan peraturan perundang-undangan lainnya yang mengatur tentang anak.

\section{Perkawinan Usia Anak dalam Perspektif Hukum Adat Bali}

Dalam hukum adat tidak ada patokan umur tertentu yang digunakan untuk menentukan kedewasaan seseorang, sehingga tidak ada keseragaman mengenai ukuran dewasa dalam hukum adat pada masing-masing daerah di Indonesia. Kondisi itu tampak dari pandangan para ahli hukum adat seperti yang dikutip oleh M. Gufron. Misalnya, Ter Haar menyatakan seseorang dianggap dewasa apabila telah cakap, sudah kawin

20 "Perempuan Korban Perkawinan Anak, Gugat Pasal 7 ayat 1 UU Perkawinan", http://www.koalisiperempuan.or.id/2017/04/20/perempuan-korban-perkawinan-anak-gugat-pasal-7-ayat-1-uu-perkawinan/, diakses tanggal 12 Maret 2019.

${ }^{21}$ Christoforus Ristianto, "MK: Aturan Batas Usia Perkawinan Perempuan Perlu Direvisi” https://nasional.kompas.com/read/2018/12/13/13361221/mk-aturan-batas-usia-perkawinan-perempuan-perlu-direvisi, diakses: 19 Februari 2019. 
dan hidup terpisah dari orang tuanya; Soepomo menyatakan ukuran dewasa apabila seseorang sudah kuwat gawe (mampu bekerja) atau cakap mengurus kepentingannya sendiri; sedangkan menurut Djojodigoeno, ukuran dewasa itu adalah apabila seseorang sudah kuwat gawe, menats atau mencar. Intinya, menurut Gufron, dalam pandangan masyarakat adat, seseorang itu sudah dewasa apabila ia sudah mampu memelihara kepentingannya sendiri. ${ }^{22}$. Tidak adanya keseragaman mengenai kreteria dewasa ini menyebabkan tidak ada pula patokan yang pasti mengenai syarat umur untuk melangsungkan perkawinan.

Dalam hukum adat Bali, sebagaimana dapat diidentifikasi dari awig-awig desa pakraman, tidak ada patokan umur tertentu sebagai syarat bagi seseorang untuk dapat melangsungkan perkawinan. Untuk dapat lebih memahami pengaturan mengenai syarat perkawinan, berikut ini dikutipkan secara lengkap salah satu ketentuan dalam awigawig desa pakraman. Pasal 56 ayat (3) Awig-awig Desa Pakraman Kesiman, Denpasar (2010) menetukan sebagai berikut.

"Pidabdab sang pacang mawiwaha:

ha. sampun manggeh daha-teruna;

na. sampun pada rena utawi tan papaksan;

ca. manut kecaping agama;

ra. kawisudayang malarapan sudi wadhani prade pangambile seosan agama".

Terjemahan bebas:

Syarat bagi seseorang agar dapat melangsungkan perkawinan:

a. sudah memasuki masa pubertas (daha-teruna);

b. berdasarkan persetujuan bersama tanpa paksaan;.

c. sesuai dengan ketentuan agama;

d. disucikan dengan upacara agama apabila mengawini orang yang berbeda agama.

Dalam ketentuan awig-awig desa pakraman di atas tidak ditentukan batasan umur tertentu bagi seseorang agar dapat melangsungkan perkawinan. Ini menunjukkan bahwa dalam hukum adat Bali tidak diatur secara kuantitatif batasan usia seseorang agar dapat melangsungkan perkawinan. Syarat yang ditekankan adalah ciri-ciri biologis yang menunjukkan kesiapan melakukan perkawinan. Ciri-ciri biologis yang disyaratkan itu ditentukan dalam norma yang dirumuskan dengan kalimat: "Pidabdab sang pacang mawiwaha...sampun daha teruna" (syarat bagi seseorang yang akan melangsungkan perkawinan harus sudah memasuki masa pubertas). Berdasarkan ketentuan ini, berapa pun umur seseorang, sepanjang yang bersangkutan sudah memasuki masa pubertas (daha teruna) sudah diperbolehkan melangsungkan perkawinan.

Konsep daha teruna bukanlah konsep kuantitatif yang menunjuk angka umur tertentu. Secara etimologis, istilah "daha-teruna" berasal dari dua kata dalam bahasa Bali, yaitu "daha" dan "teruna". Dalam kamus bahasa Bali, istilah daha (dalam kamus ditulis "daa") berarti gadis ${ }^{23}$; kata teruna berarti pemuda ${ }^{24}$. Secara sosiologis, terutama dalam penamaan organisasi kepemudaan di desa pakraman, kata daha diganti dengan kata teruni (Ind. = pemudi) sebagai lawan kata teruna. . Frasa ini (teruna-teruni) kemudian menjadi bagian dari sebutan suatu nama organisasi pemuda-pemudi di suatu desa pakraman. Misalnya organisasi pemuda-pemudi di Banjar Muding Mekar disebut Sekeha Teruna-Teruni Banjar Muding Mekar. Sebagai padanan istilah daha-teruna,

${ }^{22}$ M .Ghufron. "Makna Kedewasaan Dalam Perkawinan."Al-Hukama' 6.2 (2016), hlm. 331, http://jurnalfsh. uinsby.ac.id/index.php/alhukuma/article/view/319/269, diakses 4 Agustus 2018.

${ }^{23}$ J. Kersten S.V.D., 1984, Bahasa Bali, Penerbit Nusa Indah, Ende-Flores, hlm. 222.

${ }^{24}$ Ibid., hlm. 601. 
di daerah Bali Utara biasa digunakan istilah "bajang" untuk menyebut laki-laki dan perempuan dewasa yang masih muda; sedangkan di Bali Timur, istilah "bajang" hanya digunakan untuk perempuan saja ${ }^{25}$.

Ukuran yang lazim digunakan untuk menyebut seorang perempuan sudah dalam keadaan daha adalah apabila perempuan tersebut sudah mengalami menstruasi (haid); laki-laki sudah teruna apabila sudah menunjukkan perubahan suara serta tumbuhnya bulu pada bagian-bagian tertentu pada tubuhnya (kumis, janggut, bulu kemaluan). Tanda-tanda itu terjadi pada umur yang belum tentu sama antara anak yang satu dengan anak lainnya. Berdasarkan ajaran Hindu yang dipraktikkan oleh masyarakat adat Bali, setiap tahapan dalam siklus kehidupan manusia dari sejak dalam kandungan sampai meninggal selalu disertai dengan ritual-ritual keagamaan, yaitu upacara bayi dalam kandungan (magedong-gedongan); upacara setelah bayi lahir (pegat pusar); upacara ketika bayi berumur sekitar tiga bulan (tuun tanah); upacara menginjak dewasa (menek kelih), upacara perkawinan (mesakapan); dan upacara ketika meninggal (ngaben). Upacara menginjak remaja (menek kelih) umumnya dilakukan ketika anak perempuan mengalami menstruasi (ngerajaswala) pertama kalinya atau apabila anak laki-laki sudah pernah mimpi basah ${ }^{26}$.

Secara etimologis, frasa menek kelih berasal dari dua kata, yaitu menek dan kelih. Dalam Bahasa Bali menek berarti naik; kelih berarti dewasa. Dengan demikian, ritual ini dapat dimaknai sebagai moment religius yang menandai seseorang sudah menginjak dewasa. Secara sosial, seseorang yang sudah diupacarai menek kelih sudah diakui dan diperlakukan sebagai daha-teruna sehingga layak bergabung dalam kelompok organisasi pemuda-pemudi di desa, yang disebut Sekeha Teruna-Teruni (STT).

Dilihat dari tanda-tanda biologis dari seseorang yang sudah memasuki keadaan deha-teruna, maka seseorang yang telah memasuki daha-teruna dapat dipadankan dengan kondisi seorang anak ketika memasuki masa pubertas. Dalam ilmu kesehatan, terjadinya menstruasi (haid) pertama seorang perempuan disebut menarche, yaitu keluarnya darah dari vagina sebagai proses dari pelepasan dinding rahim (endometrium) disertai dengan perdarahan. Terjadinya menarche pada seorang perempuan menandai masa pubertas yang didefinisikan sebagai waktu tercapainya kematangan seksual, yaitu mulai berfungsinya organ reproduksi. Masa terjadinya menarche pada setiap perempuan berbeda-beda, dapat lebih awal (umur sekitar 9 sampai 11 tahun) atau lebih lambat (umur 17 tahun).(Putra,dkk., 2016, h.32). Masa pubertas laki-laki terjadi antara umur 9 tahun - 17 tahun ditandai dengan meningkatnya volume testis yang diikuti pembesaran penis dan perubahan suara (Batubara, 2019, h.25). Ini membuktikan bahwa secara biologis tidak ada ukuran umur pasti yang dapat digunakan untuk mengkualifikasikan seseorang sudah dalam keadaan daha atau teruna.

Dari paragraf-paragraf di atas, akhirnya dapat dipahami bahwa hukum adat Bali tidak mengatur secara kuantitatif mengenai batasan umur tertentu sebagai syarat bagi seseorang untuk dapat melakukan perkawinan. Kriteria yang digunakan sebagai syarat adalah kondisi biologis yang bersangkutan, yaitu sudah memasuki masa pubertas yang dalam konsep hukum adat Bali dikenal dengan istilah daha teruna. Masa pubertas itu pada umumnya sudah terjadi pada umur di bawah 18 tahun. Dengan demikian, secara normatif hukum adat Bali tidak melarang perkawinan usia anak, sepanjang anak tersebut sudah memasuki masa pubertas.

\footnotetext{
${ }^{25}$ Ibid., hlm. 172.

${ }^{26}$ IBG Yudha Triguna, "Konsep Ketuhaan dan Kemanusiaan dalam Hindu”, Dharmasmrti 1.18, hlm. 72, http:// www.dharmasmrti.com/index.php/jurnal agama/article/view/100/84, diakses tanggal 7 September 2018.
} 


\section{Kebutuhan Sinkronisasi Hukum}

Uraian di atas menunjukkan bahwa tidak ada keselarasan pengaturan perkawinan usia anak, tidak saja dalam lingkup dikotomi hukum negara dan hukum adat, melainkan juga dalam internal hukum negara. Kondisi ini diduga menjadi faktor determinan dari aspek hukum yang mempengaruhi tetap berlangsungnya praktik-praktik perkawinan usia anak di Indonesia, khususnya Bali. Oleh karena itu, Untuk mencegah tetap terjadinya perkawinan usia anak di Bali maka dibutuhkan adanya langkah-langkah untuk memperbaiki kondisi hukum yang saling bertentangan itu.

Secara teoritis, jalan keluar yang dapat ditempuh ketika menghadapi kondisi ketidaksesuaian aturan-aturan hukum adalah sinkronisasi hukum. Studi tentang sinkronisasi hukum selama ini umumnya menyangkut sinkronisasi internal hukum negara (hukum perundang-undangan). Dalam hal ini sinkronisasi hukum (syncronization of law) dipahami sebagai proses penyelarasan dan penyerasian berbagai peraturan perundang-undangan yang sudah ada dan yang sedang disusun yang mengatur suatu bidang tertentu. Kegiatan sinkronisasi hukum ini bertujuan untuk memastikan adanya keselarasan antara peraturan perundang-undangan yang satu dengan lainnya, baik antara peraturan perundang-undangan yang sederajat (sinkronisasi horisontal), maupun antara peraturan perundang-undangan yang lebih rendah derajatnya dengan peraturan perundang-undangan yang lebih tinggi (sinkronisasi vertikal). Dengan proses sinkronisasi ini diharapkan substansi yang diatur dalam peraturan perundangundangan dapat saling terkait, saling melengkapi, tidak ada yang tumpang tindih atau saling bertentangan ${ }^{27}$.

Dalam pengaturan perkawinan usia anak, kondisi yang terjadi adalah terjadinya ketidaksinkronan secara vertikal antara materi muatan Pasal 7 ayat (1) Undang-undang Perkawinan dengan pasal 27 ayat (1) UUDNRI Tahun 1945 dan ketidaksinkronan secara horizontal dengan undang-undang lain yang mengatur anak, seperti Undang-undang Perlindungan Anak, Undang-undang Pornografi, Undang-undang Ketenagakerjaan, dan lain-lain. Undang-undang lain menentukan bahwa orang yang belum berumur 18 tahun dikategorikan sebagai anak yang harus mendapatkan perlindungan, sedangkan Pasal 7 ayat (1) Undang-undang Perkawinan mengijinkan anak perempuan yang belum berusia 18 tahun untuk melangsungkan perkawinan. Untuk mengkahiri kondisi itu, maka dibutuhkan adanya langkah-langkah sinkronisasi vertikal dan horizontal dengan melakukan revisi materi muatan Pasal 7 ayat (1) Undang-undang Perkawinan dengan mengubahnya menjadi "Perkawinan hanya diizinkan jika pihak pria sudah mencapai umur 19 (sembilan belas) tahun dan pihak wanita sudah mencapai umur 18 (delapan belas) tahun".

Mengenai ketidaksingkronan pengaturan perkawinan anak antara hukum adat dengan hukum negara, sinkronisasi dapat dilakukan dengan pendekatan pluralisme hukum. Pendekatan ini dapat menjelaskan fakta empiris mengenai keberadaan dua atau lebih sistem hukum yang saling berinteraksi dalam suatu bidang sosial atau situasi hukum. Dalam konteks hubungan antara hukum negara dan hukum adat, sistem hukum Indonesia menganut pluralisme hukum lemah (week legal pluralism), karena keberlakuan hukum adat harus mendapat pengakuan dari sistem hukum negara ${ }^{28}$.

\footnotetext{
${ }^{27}$ Novoianto N. Hantoro, "Sinkronisasi dan Harmonisasi Pengaturan Mengenai Peraturan Daerah Serta Uji Materi Peraturan Daerah Provinsi Bali Nomor 16 Tahun 2009 tentang Rencana Tata Ruang Wilayah Provinsi Bali Tahun 2009-2029", hlm.8, http://perpustakaan.bappenas.go.id/lontar/file?file=digital/130881-\%5B Konten \%5D-Konten \% 20C9218.pdf, diakses 1 November 2018

${ }^{28}$ I Ketut Sudantra, 2016, Pengakuan Peradilan Adat dalam Politik Hukum Kekuasaan Kehakiman, Suasta Nulus bekerjasama dengan Bali Santi dan Puslit Hukum Adat (LPPM Unud) Denpasar, hlm. 22
} 
Secara konstitusional, landasan dianutnya pluralisme hukum lemah ini diletakkan dalam Pasal 18B ayat (2) Undang-undang Dasar Negara Republik Indonesia Tahun 1945 yang menyatakan bahwa "Negara mengakui dan menghormati kesatuan-kesatuan masyarakat hukum adat beserta hak-hak tradisionalnya sepanjang masih hidup dan sesuai dengan perkembangan masyarakat dan prinsip Negara Kesatuan Republik Indonesia yang diatur dalam undang-undang". Hukum adat adalah produk dari kesatuan masyarakat hukum adat. Dengan mengikuti konstruksi Pasal 18B ayat (2) di atas, maka pengakuan terhadap keberlakuan hukum adat juga disertai dengan syarat-syarat: (1) sepanjang masih hidup; (2) sesuai dengan perkembangan masyarakat; (3) sesuai dengan prinsip Negara Kesatuan Republik Indonesia; dan (4) diatur dalam undang-undang. Berdasarkan tafsir Mahkamah Konstitusi Republik Indonesia, hukum adat dapat dikatakan memenuhi syarat-syarat tersebut, antara lain, apabila substansi normanya sesuai dan tidak bertentangan dengan peraturan perundang-undangan ${ }^{29}$.

Dalam konteks perkawinan usia anak, hukum adat Bali tidak memberikan patokan yang jelas mengenai batas usia perkawinan. Sebagaimana telah diuraikan di depan, awig-awig desa pakraman menentukan bahwa seseorang diperbolehkan melakukan perkawinan sepanjang sudah memasuki masa pubertas (daha-teruna). Asas hukum ini sangat potensial melegalkan pekawinan usia anak sebab masa pubertas dari seseorang pada umumnya sudah terjadi pada masa seorang anak belum berumur 18 (delapan belas) tahun. Dengan demikian pengaturan mengenai syarat-syarat perkawinan dalam hukum adat Bali, sepanjang menyangkut patokan usia perkawinan, tidak sesuai dengan prinsipprinsip perlindungan anak yang diatur dalam peraturan perundang-undangan Republik Indonesia. Dengan menggunakan logika Pasal 18B ayat (2) UUD NRI Tahun 1945 dapat dipahami bahwa hukum adat Bali yang membolehkan perkawinan usia anak tidak diakui keberlakuannya oleh negara karena substansi normanya tidak sesuai dengan peraturan perundang-undangan yang berlaku. Agar keberadaan dan keberlakuan hukum adat dapat tetap diakui, maka norma-norma hukum adatlah yang harus menyesuaikan diri dengan norma-norma hukum negara. Oleh karena itu, langkah penting dan urgen yang harus dilakukan dalam rangka sinkronisasi hukum adat dengan hukum negara adalah dengan melakukan revisi terhadap awig-awig desa pakraman sepanjang menyangkut syarat mengenai batas minimal usia perkawinan. Ketentuan "sampun daha teruna" yang menjadi syarat perkawinan dalam awig-awig desa pakraman harus disesuaikan dengan ketentuan batas minimal usia perkawinan yang ditentukan dalam peraturan perundang-undangan yang berlaku.

\section{SIMPULAN}

Sebagai penutup akhirnya dapat ditegaskan simpulan dari tulisan ini. Dalam kondisi pluralisme hukum yang berlaku di bidang hukum perkawinan di Indonesia, ternyata tidak ada sinkronisasi pengaturan perkawinan usia anak, baik dalam lingkup internal hukum negara maupun dalam lingkup dikotomi hukum negara dan hukum adat.

Dalam perspektif intrernal hukum negara, Undang-undang Perkawinan memang menggunakan kriteria umur tertentu yang sebagai batas usia perkawinan, namun ketentuan batas usia perkawinan yang diatur dalam Pasal 7 ayat (1) undang-undang tersebut bertentangan dengan asas-asas yang dianut dalam Pasal 27 ayat (1) UUDNRI

\footnotetext{
${ }^{29}$ Mahkamah Konstitusi Republik Indonesia, "Putusan Nomor 31/PUU-V/2007 dalam Perkara Permohonan Pengujian Undang-Undang Nomor 31 Tahun 2007 tentang Pembentukan Kota Tual Di Provinsi Maluku terhadap Undang-Undang Dasar Negara Republik Indonesia Tahun 1945”, diucapkan dalam Sidang Pleno terbuka untuk umum pada hari Rabu, 18 Juni 2008, hlm. 165-166, https://mkri.id/index.php?page = web.RisalahSidang\&id $=1 \&$ kat $=1 \&-$ $\underline{\text { menu }=4}$, diakses 2 Juni 2012
} 
Tahun 1945 dan bertentangan pula dengan undang-undang lain yang mengatur masalah anak, seperti Undang-undang Perlindungan Anak, Undang-undang Pornografi, Undang-undang Ketenagakerjaan, dan lain-lain. Berbeda dengan sistem hukum negara, sistem hukum adat (Bali) tidak menggunakan kreteria umur tertentu sebagai syarat perkawinan. Hukum adat menggunakan kriteria berupa tanda-tanda fisik (biologis) dari seseorang yang menunjukkan kematangannya untuk kawin, yaitu sudah memasuki masa pubertas (Bali: daha-teruna). Masa pubertas setiap orang bisa berbeda-beda, yang dapat sudah terjadi antara usia 9-17 tahun. Itu menunjukkan hukum adat Bali tidak melarang perkawinan usia anak sepanjang anak itu sudah memasuki masa pubertas (deha-teruna). Norma hukum adat yang demikian itu tidak sesuai ketentuan peraturan perundang-undangan, yang tidak menghendaki terjadinya perkawinan usia anak.

Kondisi ketidaksinkronan hukum di atas dapat menghambat usaha-usaha untuk mengakhiri atau setidak-tidaknya mengurangi praktik-praktik perkawinan usia anak di Indonesia. Sebagai solusi, sangat dibutuhkan adanya sinkronisasi hukum dalam pengaturan perkawinan anak. Dalam lingkup hukum negara, langkah sinkronisasi dapat dilakukan dengan melakukan revisi terhadap materi muatan Pasal 7 ayat (1) Undang-undang Perkawinan. Revisi ini urgen dilakukan di samping karena aturan batas usia perkawinan dalam Undang-undang Perkawinan bersifat diskriminatif, juga sesuai dengan kehendak Putusan Mahkamah Konstitusi Republik Indonesia yang meminta pembuat undang-undang agar segera melakukan perubahan terhadap Undang-undang Perkawinan, khususnya menyangkut batas usia minimal perempuan dalam perkawinan.. Dalam lingkup lokal Bali, langkah sinkronisasi hukum dapat dilakukan dengan merevisi awig-awig desa pakraman, sepanjang menyangkut syarat batas usia perkawinan dengan menyesuaikannya dengan ketentuan peraturan perundang-undangan yang berlaku.

\section{DAFTAR PUSTAKA}

\section{Buku}

Direktorat Statistik Kesejahteraan Rakyat, (2017). Perkawinan Usia Anak di Indonesia (2013 dan 2015), Edisi Revisi, Badan Pusat Statistik-UNICEF Indonesia, Jakarta.

Efendi, Jonaedi \& Johnny Ibrahim, (2018). Metode Penelitian Hukum Normatif dan Empiris, cetakan kedua, Prenadamedia Group, Indonesia

Kersten S.V.D., J., 1984, Bahasa Bali, Penerbit Nusa Indah, Ende-Flores.

Subdirektorat Statistik Rumah Tangga, (2016). Kemajuan Yang Tertunda: Analisis Data Perkawinan Usia Anak di Indonesia, Badan Pusat Statistik - UNICEF, Jakarta.

Sudantra, I Ketut, (2016). Pengakuan Peradilan Adat dalam Politik Hukum Kekuasaan Kehakiman, Suasta Nulus bekerjasama dengan Bali Santi dan Puslit Hukum Adat (LPPM Unud) Denpasar

\section{Journal dan Karya Ilmiah Lain:}

Djamilah, D., \& Kartikawati, R. (2016). Dampak Perkawinan Anak di Indonesia. Jurnal Studi Pemuda, 3(1), 1-16. https://jurnal.ugm.ac.id/jurnalpemuda/article/ view/32033/19357, diakses tanggal 12 Maret 2019.

Erdianto, Kristian, "Presiden Jokowi Harus Melihat, Perkawinan Anak Sudah Darurat", https://nasional.kompas.com/read/2018/04/18/06430291/presiden-jokowi-harusmelihat-perkawinan-anak-sudah-darurat, diakses tanggal 18 Agustus 2018. 
Haikal, H. (2016). ANALISIS YURIDIS NORMATIF DAN HUKUM ISLAM TERHADAP PUTUSAN MAHKAMAH KONSTITUSI NOMOR 30-74/PUUXII/2014 TENTANG BATAS USIA PERKAWINAN ANAK (PEREMPUAN) ABDUL HADI DAN HASANAIN HAIKAL. YUDISIA: Jurnal Pemikiran Hukum dan Hukum Islam, 7(1), 238-266., http://journal.stainkudus.ac.id/index. php/Yudisia/article/view/2138/1770. diakses tanggal 3 September 2018.

Hasan, H. (2018). PERNIKAHAN DI BAWAH UMUR (Analisis tentang Konsekuensi Pemidanaan). Al Daulah: Jurnal Hukum Pidana dan Ketatanegaraan, 6(1), 86-120. http://journal.uin-alauddin.ac.id/index.php/al daulah/articlel view/4869/4357, diakses tanggal 18 Agustus 2018

Hantoro, Novoianto N., "Sinkronisasi dan Harmonisasi Pengaturan Mengenai Peraturan Daerah Serta Uji Materi Peraturan Daerah Provinsi Bali Nomor 16 Tahun 2009 tentang Rencana Tata Ruang Wilayah Provinsi Bali Tahun 20092029", $\quad$ http://perpustakaan.bappenas.go.id/lontar/file?file = digital/130881\%5B Konten \%5D-Konten \% 20C9218.pdf, diakses 1 November 2018

Fuad, A. M. (2015). Menelaah Kembali Ketentuan Usia Minimal Kawin di Indonesia Melalui Perspektif Hermeneutika. Al-Maslahah, 11(2)., https:// jurnaliainpontianak.or.id/index.php/Almaslahah/article/view/145/254, diakses tanggal 23 Agustus 2018.

Ghufron, M. (2016). MAKNA KEDEWASAAN DALAM PERKAWINAN. ALHUKAMA', 6(2), 319-336. http://jurnalfsh.uinsby.ac.id/index.php/alhukumal article/view/319/269, diakses 4 Agustus 2018

Liputan6, "Pernikahan Dini, Fenomena Gunung Es", https://www.liputan6.com/news/ read/354833/pernikahan-dini-fenomena-gunung-es, diakses tanggal 18 Agustus 2018.

Nurjaya, I. N. (2014). Constitutional And Legal Recognition Over Traditional Adat Community Within The Multicultural Country Of Indonesia: Is It A Genuine Or Pseudo Recognition?. Jurnal IUS Kajian Hukum dan Keadilan, 2(3).

Panggabean, R. M., (2010). “Keabsahan Perjanjian dengan Klausul Baku.” Jurnal Hukum Ius Quia Iustum 17.4, http://journal.uii.ac.id/IUSTUM/article/view/3935/3514, diakses tanggal 22 Agustus 2018.

Prameswari, Z. W. A. W. (2017). Ratifikasi Konvensi Tentang Hak-Hak Anak Dalam Sistem Peraturan Perundang-Undangan Di Indonesia. Yuridika, 32(1), 167188., https://e-journal.unair.ac.id/YDK/article/view/4842/pdf , diakses tanggal 23 Agustus 2018

Rifiani, D. (2011). Pernikahan dini dalam perspektif hukum islam. Journal de Jure, 3(2), http://ejournal.uin-malang.ac.id/index.php/syariah/article/view/2144, diakses tanggal 12 Maret 2019

Rohmat, "LPA Bali Telusuri Kasus Pernikahan Bocah SD dan Pria 40 Tahun”, $\underline{h t t p s: / /}$ news.okezone.com/read/2013/01/30/340/753711/lpa-bali-telusuri-kasuspernikahan-bocah-sd-dan-pria-40-tahun, diakses tanggal 18 Agustus 2018.

Sudantra, I Ketut dan I Gusti Ngurah Dharma Laksana, (2017). "Pluralisme Hukum Yang Berlaku dalam Perkawinan Umat Hindu di Bali”, Prosiding Seminar Sains \& Teknologi IV 2017, Lembaga Penelitian dan Pengabdian Kepada Masyarakat 
Universitas Udayana -Udayana University Press, Denpasar.

Sudantra, I. K. (2015). Identifikasi Lingkup Isi dan Batas-batas Otonomi Desa Pakraman dalam Hubungannya dengan Kekuasaan Negara. Jurnal Magister Hukum Udayana (Udayana Master Law Journal), 4(1). https://ojs.unud.ac.id/index. php/jmhu/article/view/13052/10829, diakses tanggal 2 September 2018.

Triguna, I. Y. (2018). Konsep Ketuhanan dan Kemanusiaan dalam Hindu. DHARMASMRTI: Jurnal Pascasarjana UNHI, 1(18), 71-83. http://www. dharmasmrti.com/index.php/jurnal agama/article/view/100/84, diakses tanggal 7 September 2018.

Mahkamah Konstitusi Republik Indonesia, "Putusan Nomor 31/PUU-V/2007 dalam Perkara Permohonan Pengujian Undang-Undang Nomor 31 Tahun 2007 tentang Pembentukan Kota Tual Di Provinsi Maluku terhadap Undang-Undang Dasar Negara Republik Indonesia Tahun 1945”, diucapkan dalam Sidang Pleno terbuka untuk umum pada hari Rabu, 18 Juni 2008, https://mkri.id/index. php?page $=$ web. RisalahSidang\&id $=1 \& \mathrm{~kat}=1$ \&menu $=4$, diakses 2 Juni 2012.

\section{Peraturan Perundang-undangan:}

Undang-undang Republik Indonesia Nomor 1 Tahun 1974 tentang Perkawinan (Lembaran Negara Republik Indonesia Tahun 1974 Nomor 1; Tambahan Lembaran Negara Republik Indonesia Nomor 3019)

Undang-undang Nomor 23 Tahun 2002 tentang Perlindungan Anak (Lembaran Negara Republik Indonesia Tahun 2003 Nomor 92; Tambahan Lembaran Negara Republik Indonesia Nomor 4310)

Undang-undang Nomor 35 Tahun 2014 tentang Perubahan Atas Undang-undang Nomor 23 Tahun 2002 tentang Perlindungan Anak (Lembaran Negara Tahun 2014 Nomor 297; Tambahan Lembaran Negara Nomor 5606)

Undang-undang Nomor 44 Tahun 2008 tentang Pornografi (Lembaran Negara Republik Indonesia Tahun 2008 Nomor 181; Tambahan Lembaran Negara Republik Indonesia Nomor 4928)

Undang-undang Nomor 13 Tahun 2003 Undang-undang Ketenagakerjaan (Lembaran Negara Tahun 2003 Nomor 39; Tambahan Lembaran Negara Nomor 4279)

Undang-undang Nomor 39 Tahun 1999 tentang Hak Asasi Manusia (Lembaran Negara Republik Indonesia Tahun 1999 Nomor 98; Tambahan Lembaran Negara Republik Indonesia Nomor 4316)

\section{Website:}

Erdianto, Kristian, "Presiden Jokowi Harus Melihat, Perkawinan Anak Sudah Darurat", https://nasional.kompas.com/read/2018/04/18/06430291/presiden-jokowi-harusmelihat-perkawinan-anak-sudah-darurat, diakses tanggal 18 Agustus 2018.

Liputan6, "Pernikahan Dini, Fenomena Gunung Es", https://www.liputan6.com/news/ read/354833/pernikahan-dini-fenomena-gunung-es, diakses tanggal 18 Agustus 2018.

Ristianto, Christoforus, "MK: Aturan Batas Usia Perkawinan Perempuan Perlu Direvisi" https://nasional.kompas.com/read/2018/12/13/13361221/mk-aturan-batasusia-perkawinan-perempuan-perlu-direvisi, diakses: 19 Februari 2019. 